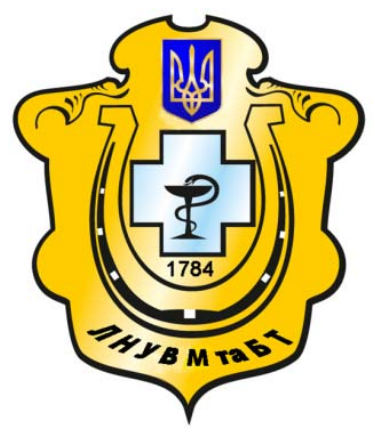

Науковий вісник Львівського національного університету ветеринарної медицини та біотехнологій імені С.3. Гжицького

Scientific Messenger of Lviv National University of Veterinary Medicine and Biotechnologies named after S.Z. Gzhytskyj

doi:10.15421/nvlvet7029

ISSN 2413-5550 print

ISSN 2518-1327 online

$\underline{\text { http://nvlvet.com.ua/ }}$

УДК619:615.322

\title{
Перспективи застосування чубушника як лікарської рослини
}

\author{
В.Д. Іщенко, С.М. Костенко, В.М. Костенко, Ю.В. Тимошик \\ ischenkovd@ukr.net
}

Національний університет біоресурсів і природокористування Украӥни, вул. Героїв Оборони, 15, м. Київ, 03041, Україна

\begin{abstract}
Арсенал лікарських рослин є недостатньо вивченим і практично невичерпним. Застосування фітопрепаратів дає можливість зменшити ксенобіотичний вплив на організм тварин через природне походження діючих речовин, а супутні $і$ допоміжні згладжують основну дію і попереджають прояв побічних ефектів. Однією із таких рослин, можливості використання якої у ветеринарній практиці ще недостатньо вивчені є чубушник. Враховуючи важливу роль фенольних сполук у регуляції метаболізму рослин та багатогранність впливу ичих речовин на організм тварин і людини, у листках чубушників різних сортів було визначено вміст вторинних метаболітів фенольної природи для виявлення перспектив подальшого їх застосування у ветеринарній медицині. Якісними реакиіями з реактивом Вільсона, розчином феруму (III) хлориду та за ціанідиновою реакцісю у екстрактах із листя чубушника встановлено наявність фенольних сполук. Подальшими фітохімічними дослідженнями встановлено, що вміст фенолів у екстрактах чубушників знаходиться в межсах від 33,0 \pm 0,48 мг/2 (y Philadelphus L. 'Innocence') до 107,1 $\pm 0,91$ мг/2 (y Philadelphus L. 'Avalanche'). Вміст флавоноїдів у спиртових екстрактах із листя чубушника різних видів коливається в межах від 5,3 \pm 0,41 до 10,6 \pm 0,41 мг/2. Найбільша концентрація флавоноїдів за відносно невисокого вмісту фенолів міститься у екстракті з листя Philadelphus coronarius 'Naпа' (чубушника карликової форми), застосування якого поряд із Philadelphus L. 'Avalanche' може бути перспективним у медичній $i$ ветеринарній практиці, зважаючи на високі концентрації фенолів та флавоноїдів і кумаринів у цих сортах чубушників.
\end{abstract}

Ключові слова: лікарські рослини, рід PhiladelphиsL, чубушник, листя, екстракт, фітохімічний аналіз, метаболіти, феноли, флавоноїди, кумарини.

\section{Перспективы применения чубушника как лекарственного растения}

\author{
В.Д. Ищенко, С.Н. Костенко, В.М. Костенко, Ю.В. Тимошик \\ ischenkovd@ukr.net
}

Национальный университет биоресурсов и природопользования Украины,, ул. Героев Обороны, 15, г. Киев, 03041, Украина

\begin{abstract}
Арсенал лекарственных растений является недостаточно изученным и практически неисчерпаемым. Применение фитопрепаратов дает возможность уменьшить ксенобиотическое влияние на организм животных вследствие естественного происхождения действующих веществ, а сопутствующие и вспомогательные сглаживают основное действие и предупреждают проявление побочных эффектов. Одним из таких растений, возможности использования которого в ветеринарной практике еще недостаточно изучены является чубушник. Учитывая важную роль фенольных соединений в регуляции метаболизма растений и многогранность влияния этих веществ на организм жсивотных и человека, в листьях чубушников разных сортов было определено содержание вторичных метаболитов фенольной природы для выявления перспектив дальнейшего их применения в ветеринарной медииине. Качественныли реакциями с реактивом Вильсона, раствором сульфата железа (III) хлорида и по иианидиновой реакиии в экстрактах из листьев чубушника установлено наличие фенольных соединений. Последующими фитохимическими исследованиями установлено, что содержание фенолов в исследуемых экстрактах находится в пределах от 33,0 $\pm 0,48$ до 107,1 $\pm 0,91$ мг/2 (Philadelphus L. 'Avalanche'). Содержание флавоноидов 6 спиртовых экстрактах из листьев чубушника разных видов колеблется в пределах от 5,3 \pm 0,41 до 10,6 0,41 мг/2. Наибольшее количество флавоноидов при относительно невысокой конщентрации фенолов содержится в препарате из листьев
\end{abstract}

Ishchenko, V.D., Kostenko, S.V., Kostenko, V.M., Tymoshyk, Y.V. (2016). Prospects for use a mock-orange as medicinal plant. Messenger LNUVMBT named after S.Z. Gzhytskyj, 18, 3(70), 123-127. 
Philadelphus coronarius 'Nana' (чубушника карликовой формы), применение которого наряду с Philadelphиs L. 'Avalanche' может быть перспективным в медицинской и ветеринарной практике, учитывая высокие концентрации фенолов, флавоноидов и кумаринов в этих сортах чубуиников.

Ключевые слова: лекарственные растения, род Philadelphus L, чубуиник, листья, экстракт, фитохимический анализ, метаболиты, феноль, флавоноидыл, кумаринь

\title{
Prospects for use a mock-orange as medicinal plant
}

\author{
V.D. Ishchenko, S.V. Kostenko, V.M. Kostenko, Y.V. Tymoshyk \\ ischenkovd@ukr.net
}

\author{
National university of life and environmental sciences of Ukraine, \\ Heroyiv Oborony Str., 11, Kyiv, 03041, Ukraine
}

\begin{abstract}
Medicinal plants are insufficiently studied and almost endless. The use of phytomedication enables reduce the impact of xenobiotics on animals organism through the natural origin of active compounds and associated and auxiliary substances smoothing the basic action and prevent the manifestation of side effects. One of such plants the possibility of using in veterinary practice is still insufficiently studied is mock-orange. Considering on the important role of phenolic compounds in the metabolic regulation of plant and diversity of impact of these substances on organism of animals and humans, in leaves of mock-oranges different cultivar was identified the content of phenolic secondary metabolites to identify the prospects for their further using in veterinary medicine. The qualitative reaction with the Wilson reagent, solution of iron (III) chloride and by cyanidin reaction in extracts from mock-orange leaves was established the presence of phenolic compounds. Further phytochemical investigations established that the content of phenols in the investigated extracts is between $33.0 \pm 0.48$ to $107.1 \pm 0.91 \mathrm{mg} / \mathrm{g}$ (in Philadelphus L. 'Avalanche'). The content of flavonoids in alcohol extracts from leaves of different species of mock-oranges varies from $5.3 \pm 0.41$ to $10.6 \pm 0.41 \mathrm{mg} / \mathrm{g}$. Greatest quantity of flavonoids at relatively of low content of phenols contained in the preparation from leaves of Philadelphus coronaries 'Nana '(mock-orange dwarf), the use of which, along with Philadelphus L. 'Avalanche' can be perspective in medical and veterinary practice, considering on the high concentration of phenols and flavonoids and coumarins in these mock-oranges breed.

Key words: medicinal plants, genus Philadelphus L., mock-orange, leaves, extracts, phytochemical analysis, metabolites, phenols, flavonoids, coumarins
\end{abstract}

\section{Ветуп}

Рослинний світ планети вивчено не більше, ніж на 4\%, а з ростучих на території України майже 26 тис. видів рослин вивчено лише 5000, з яких поглиблено 500, і тільки близько 200 видів рослин мають практичне застосування. Арсенал лікарських засобів становить близько 5000 хімічних сполук, а найменувань препаратів - понад 150 тис., з яких рослинних препаратів - біля 40\%. Лікарські рослини - традиційна сировина для виготовлення ліків. Сьогодні третину лікарських засобів отримують саме $з$ рослинної сировини. Висока ефективність фітотерапії підтверджена багатовіковим дослідженням, зумовлює широке застосування препаратів на основі рослинної сировини у клінічній практиці. Багатьох клініцистів застосування фітопрепаратів приваблює тим, що їх застосування супроводжується мінімальною кількістю побічних ефектівта сумісністю з більшістю інших лікарських засобів (Hrodzinskyi, 1990).

За даними ВОО3, фітопрепарати сьогодні представляють собою ринок в 60 млрд. дол. Досить широко вони використовуються у Німеччині, Франції, США, Італії, Індії (25 - 50\%). На українському фармацевтичному ринку частка фітопрепаратів широкого спектру лікувально-профілактичної дії в середньому складає понад 45\%. Нині спостерігають зростання як фармацевтичних фірм, які випускають рослинні препарати, так і об’ємів цієї продукції.3 економічної точки зору ринок лікарських рослин $є$ надзвичайно перспективним. Про це свідчить, у першу чергу, високий рівень рентабельності.
Для пошуку нових, перспективних у плані практичного застосування, лікарських рослин важливе значення передовсім мають відомості народної та нетрадиційної медицини, хоча вони і потребують ретельної перевірки. Але стосовно рослин, які здавна застосовуються у народній медицині різних країн світу, то наукові дослідження щодо можливостей їх обгрунтованого застосування завжди актуальні. Особливо упродовж останнього періоду, коли фітотерапія, як метод лікування натуральними препаратами, набуває все більшої популярності.Упродовж останніх 10 - 15ти років видовий склад лікарських рослин майже не змінився, водночас обсяги заготівлі, як у цілому, так і окремих видів суттєво зменшуються кожні $3-5$ років, оскільки вичерпуються природні запаси цих рослин. Це спонукає до пошуку нових, перспективних у плані практичного застосування, лікарських рослин (Hrodzinskyi, 1990; Piniazhko et al., 2010).

Досі практично не використаними у медичній та ветеринарній практиці $є$ препарати із чубушника. В Україні цю рослину знають здавна під назвою жасмин садовий. Хімічний склад різних видів чубушникапоки що недостатньо вивчено. Однак наукові дослідження виявили, що квітки й листя рослини багаті на флавоноїди, містять корисний алкалоїд жасмінін, урсулову, саліцилову, бензойну, мурашину кислоти; а насіння жирну олію, яку застосовують у медицині та косметологіï (Grančai et al., 1999; Jantová et al., 2000).

На території України культивують 42 види та гібриди, а також 20 культиварів роду Philadelphus L. Інтродукція зазначеного роду на територію України має давню історію. Українські селяни здавна цінували чубушник за його невибагливість, аромат та медонос- 
ні властивості. Наукові повідомлення про вирощування рослини в Українізустрічаються вже у 50-х роках XIX століття в книзі Я. Лангера «Дерева і чагарники зелених насаджень м. Львова», де серед екзотів був також і чубушник звичайний (Kucheriavyi, 2004). Сьогодні за даними літератури представники роду Philadelphus L. інтродуковані майже по всій території України, від Закарпаття до Донбасу (Kolisnichenko et al., 2011). Багатий хімічний склад рослини відкриває перспективи застосування препаратів чубушника у різних напрямах медицини, як у дерматології, так і у «внутрішній медицині». Особливо цінною $є$ наявність у рослині значної кількості фенольних сполук, у першу чергу флавоноїдів, а також ефірних олій.

Метою роботи було визначення фітохімічними дослідженнями вмісту фенольних сполук у листі дикорослих та введених у інтродукцію чубушників(роду Philadelphus L.) для виявлення перспектив подальшого їх застосування у ветеринарній медицині.

\section{Матеріал і методи досліджень}

Фітохімічні дослідження проведені співробітниками проблемної науково-дослідної лабораторії фітовірусології та біотехнології НУБіП України.

Вміст розчинних поліфенолів визначали за методом Folin-Ciocoalteu в модифікації SingletonRossi, який базується на реакції фенолів з реактивом Фоліна-Чокальтеу. Реактив складається з суміші фосфорно-вольфрамової й фосфорно-молібденової кислот, які відновлюються при окисненні фенолів до суміші оксидів. При цьому утворюється блакитне забарвлення, яке пропорційне кількості фенольних речовин, загальний вміст яких оцінювали спектрофотометрично на спектрофотометрі Optizen POP (Корея). Для визначення оптичної густини використовували стандартні кювети, для проведення експерименту заповнювали пробірки 0,5 мл екстракту, 2,5 мл розведеного реактиву Фоліна-Чокальтеу, через 3 хв додавали 2,5 мл $\mathrm{Na}_{2} \mathrm{CO}_{3}$. У контрольні пробірки відповідно додавали по 0,5 мл 80\% етанолу. Пробірки з сумішшю добре струшували і залишали на 2 години. При побудові калібрувальної кривої використовували такі самі кювети, що і в експерименті. Вміст фенольних сполук в екстракті визначали за допомогою калібрувальної кривої, побудованої по галовій кислоті. Далі розраховували вміст внутрішньоклітинних фенольних сполук у зразку за формулою:

$\Phi=(\mathrm{C} \times \mathrm{V}$ екстракту $) /(\mathrm{m} \times 1000)$, де

$\Phi$ - загальний вміст внутрішньоклітинних фенольних сполук, мг. $\Gamma^{-1}$;

C - концентрація фенольних сполук, л;

V екстракту - загальний об'єм екстракту, мл;

$\mathrm{m}$ - маса наважки, г;

1000 - коефіцієнт переведення л в мл (об’єму екстракту).

Для кількісного визначення суми флавоноїдів у зразках чубушників використовували методику спектрофотометричного аналізу. Для цього сухе листя чубушників зважували на електронних вагах і екстрагували етанолом (1:10) та проводили аналіз калібрувальної кривої по кверцетину (Kovalev et al., 2003).
Виділення суми кумаринів із листків чубушників проводили за допомогою екстракції спиртовими сумішами 3 подальшою обробкою одержаного залишку неполярним розчинником. Для аналізу брали метанольний екстракт і хлороформ у співвідношенні 15:85, потім додавали дистильовану воду і $2 \%$ розчин $\mathrm{NaCl}$ перемішуючи отриману суміш упродовж 2 хв, залишали до повного розділення фаз. Верхній водний шар переносили в епендорфи 3 додаванням дистильованої води. Оптичну густину отриманого розчину вивчали за допомогою спектрофотометра за довжини хвилі 290 нм. Розрахунки проводили за формулою:

$$
\mathrm{X}=\frac{D * 100 * 100 * 10}{650 * m * 20(100-W)},
$$

$\mathrm{D}$ - оптична густина досліджуваного розчину при $290 \mathrm{HM}$;

650 - питомий показник поглинання псоралену при 290 нм;

m - маса наважки сировини, г;

W - вміст вологи в сировині, \% (Kovalev et al., 2003).

\section{Результати та їх обговорення}

Спиртові екстракти досліджували на наявність флавоноїдів у якісних реакціях. При цьому спостерігали жовте забарвлення 3 реактивом Вільсона (реакція 3 борно-лимонним реактивом); фіолетове забарвлення з $3 \%$ розчином феруму (III) хлориду; червоне забарвлення за ціанідиновою реакцією (до 1 мл очищеного екстракту додають по 2 - 3 краплі концентрованої кислоти хлористоводневої і щіпку порошку Магніюметалічного); з'являється забарвлення різного кольору, (залежно від будови сполук) внаслідок утворення ціанідинів. 3 метою з'ясування природи флавоноїдів після проведення ціанідинової реакції отриману суміш розбавляли рівною кількістю води, додавали 1 млоктанолу і збовтували. Інтенсивність забарвлення водного шару майже не змінювалася, що вказує на наявність флавоноїдних сполук глікозидного характеру. Фітохімічними дослідженнями із кількісного визначення фенольних сполук було встановлено, що листки зазначених чубушників містять значну кількість різних фенолів (оксикоричних кислот, флавоноїдів, кумаринів). Отримані результати 3 визначення вмісту різних фенольних сполук у спиртових екстрактах чубушників (у перерахунку на галову кислоту) представлені в табл.

Найбільший вміст фенольних сполук виявлено у листі інтродукованого чубушникаPh. L. 'Avalanche',

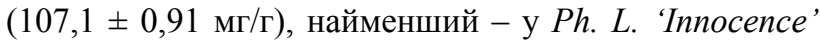
$(33,0 \pm 0,48$ мг/Г). У інших представників роду Philadelphus L. загальний вміст фенолів коливається в межах від 43,2 $\pm 0,95$ мг/г (Ph. L. 'Albatre') до $85,2 \pm 0,76 \mathrm{мг} / \Gamma$ (Ph. coronarius 'Nana').

Певні відмінності чубушників за вмістом фенолів, очевидно, пов'язані з сортовими особливостями, а також заходами з догляду за рослинами у природі чи в процесі вирощування, що впливає на загальні процеси пластичного обміну в рослині та, як наслідок, ступінь накопичення різних вторинних метаболітів, яким $\epsilon$ фенольні сполуки. 
Вміст фенольних сполук у листках представників роду Philadelphus L.

\begin{tabular}{|c|c|c|c|c|}
\hline Назва & $\begin{array}{c}\text { Феноли, } \\
\text { мг/г }\end{array}$ & $\begin{array}{c}\text { Флавоноїди, } \\
\text { мг/г }\end{array}$ & $\begin{array}{c}\text { Відношення } \\
\text { феноли / } \\
\text { флавоноїди }\end{array}$ & $\begin{array}{c}\text { Кумарини, } \\
\text { мг/г }\end{array}$ \\
\hline Ph. L. 'Avalanche' & $107,1 \pm 0,91$ & $10,6 \pm 0,41$ & 10,10 & $17,0 \pm 0,31$ \\
\hline Ph. L. 'Albatre' & $43,2 \pm 0,95$ & $7,8 \pm 0,37$ & 5,54 & $11,0 \pm 0,27$ \\
\hline Ph. L. 'Innocence' & $33,0 \pm 0,48$ & $5,3 \pm 0,41$ & 6,23 & $6,0 \pm 0,31$ \\
\hline Ph. coronarius 'Nana' & $85,2 \pm 0,76$ & $10,4 \pm 0,27$ & 8,19 & $9,0 \pm 0,29$ \\
\hline Ph. coronarius & $68,0 \pm 0,56$ & $7,0 \pm 0,17$ & 9,71 & $5,0 \pm 0,14$ \\
\hline
\end{tabular}

Останні мають здатність проявляти вплив на захисні функції тваринного організму, зокрема, діючи як антиоксиданти, гепато- і ангіопротектори, а також володіють антибіотичними властивостями.

Чисельними дослідженнями закордонних учених було виявлено, що екстракти 3 листків і пагонів Philadelphus L. володіють значною антибактеріальною, антиоксидантною і протипухлинною активністю (Grančai et al., 1999; Jantová et al., 2000; Valko et al., 2006; Valko et al., 2008; Valko et al., 2011).

За умов суттєвого варіювання загального вмісту фенолів істотно не змінювався відносний вміст флавоноїдів, що залучаються до широкого спектру регуляторних і адаптаційних механізмів в організмі рослин. Найбільший вміст флавоноїдів, як і фенольних сполук, виявлено у листі інтродукованого чубушникаPh. L. 'Avalanche', а найменший - у Ph. L. 'Innocence'. Проте максимальний та мінімальний вмісти фенольних сполук у цих сортах чубушника різнилися у 3,25 раза, а флавоноїдів - вдвічі. Різниця вмісту кумаринів у чубушниках різних сортів була більшою порівняно із вмістом флавоноїдів та не мала певного взаємозв'язку із вмістом фенолів, однак, слід зазначити, що вміст цих сполук також був найбільшим у $P h$. L. 'Avalanche'.

\section{Висновки}

1. У доступній літературі існує значна кількість повідомлень про застосування препаратів чубушників у медичній практиці з лікувальною і профілактичною метою за різних показань. Наявність у рослині ефірної олії та фенольних сполук передбачає широкі перспективи до практичного застосування препаратів чубушника в медицині та ветеринарії.

2. Якісними реакціями 3 реактивом Вільсона (утворення жовтого забарвлення), розчином феруму (III) хлориду (фіолетове забарвлення) та за ціанідиновою реакцією (червоне забарвлення) у екстрактах із листя чубушника встановлено наявність фенольних сполук.

3. Фітохімічними дослідженнями встановлено, що за вмісту фенолів у межах від $33,0 \pm 0,48$ до 107, $1 \pm 0,91$ мг/Г вміст флавоноїдів у спиртових екстрактах із листя різних видів жасмину коливається в межах від 5,3 $\pm 0,41$ до 10,6 $\pm 0,41$ мг/г. Найбільша концентраціяфлавоноїдів за відносно невисокого вмісту фенолів міститься у препараті з листя Philadelphuscoronarius 'Nana'.

4. Найбільш перспективними для подальших досліджень 3 метою встановлення можливостей практич- ного застосування у медицині та ветеринарії $\epsilon$ Philadelphus L. 'Avalanche' та Philadelphuscoronarius 'Nana', у спиртових екстрактах iз листя яких виявлено найвищі концентрації фенолів та флавоноїдів і кумаринів зокрема.

Перспективи подальших досліджень. Доклінічні і клінічні випробування на лабораторних і продуктивних тваринах лікарських препаратів, виготовлених із сортів чубушника, у яких фітохімічними дослідженнями виявлено високі концентрації фенолів, особливо флавоноїдів та кумаринів.

\section{Бібліографічні посилання}

Hrodzinskyi, A.M. (1990). Likarski roslyny: Entsyklopedychnyi dovidnyk K.: URE (in Ukrainian).

Kolisnichenko, O.M., Boniuk, Z.H., Hrevtsova, H.T. (2011). Introduktsiia derevnykh roslyn $u$ Botanichnomu sadu im. akad. O. V. Fomina (18392009): monohrafiia / [ta in.]; za red. H. T. Hrevtsovoi. - K. : VPTs «Kyivskyi universytet» (in Ukrainian).

Kucheriavyi, V.P. (2004). Introduktsiia derevnykh i chaharnykovykh porid ta problemy yikh okhorony na prykladi m. Lvova. Naukovyi visnyk: Zapovidna sprava v Halychyni, na Podilli ta Volyni. Lviv : UkrDLTU. 14.8, 134-139.

Kovalev, V.N., Popova, N.V., Kislichenko, V.S. (2003). Praktykum po farmakohnozii; pod red. V. N. Kovaleva. - Kh.: Zolotyie stranitsy (in Ukrainian).

Piniazhko, O.R., Vashchenko, K.F., Holeiko, D.V., Demianchuk, L.D. (2010). Preparaty z zhyvokostom yak efektyvni zneboliuvalni ta protyzapalni zasoby [elektronnyi resurs]. Apteka online. 14(735). Rezhym dostupu: http://www.apteka.ua/article/32168 (in Ukrainian).

Jantová, S., Nagy, M., Ružeková, L., Grančai, D. (2000). Antibacterial activity of plant extracts from the families Fabaceae, Oleaceae, Philadelphaceae, Rosaceae and Staphyleaceae. Phytotherapy Research. 14(8), 601-603.

Valko V., Fickova M., Pravdova E. (2006). Cytotoxicity of water extracts from leaves and branches of Philadelphus coronarius L. Biomedical papers of the Medical Faculty of the University Palacký, Olomouc, Czech Repub. 150, 1, 71-73.

Grančai, D., Mučaji, P., Nagy, M. (1999). Stanovenie vybranych sekundarnych metabolitov a extraktivnych latok vo Philadelphus coronarius L. Česká a Slovenská farmacie. 48(6), 265-267.

Val'ko, V., Černochová, S., Grančai, D. (2011). The determination of coumarins in extracts from plants of the 
genus Philadelphus L. Acta Facultatis Pharmaceuticae Universitatis Comenianae. V. LVIII, 1, 87-92.

Val'ko, V., Černochová, S., Grančai, D. (2008). The determination of coumarins in extracts from plants of the genus Philadelphus L. and their antioxidative activity. 14th Professional Workshop: The Actual challenges in the medicinal and aromatic plants cultivation. Book of abstracts. Mendel university in Brno, 119-123.

Стаття надійшла до редакиії 27.09.2016 